\section{Mulch and Fertilizer Management Practices for Organic Production of Highbush Blueberry. I: Plant Growth and Allocation of Biomass during Establishment}

\author{
Handell Larco ${ }^{1}$ and Bernadine C. Strik ${ }^{2,3}$ \\ Department of Horticulture, Oregon State University, 4017 ALS, Corvallis, \\ OR 97331 \\ David R. Bryla \\ U.S. Department of Agriculture-Agricultural Research Service, Horticultural \\ Crops Research Unit, 3420 NW Orchard Avenue, Corvallis, OR 97330
}

\section{Dan M. Sullivan \\ Department of Crop and Soil Science, Oregon State University, 3045 ALS, Corvallis, OR 97331}

Additional index words. compost, dry weight partitioning, feather meal, fish emulsion, landscape fabric, organic fertilizer, raised beds, sawdust, Vaccinium corymbosum, weed mat

\begin{abstract}
A systems trial was established in Oct. 2006 to evaluate management practices for organic production of northern highbush blueberry (Vaccinium corymbosum L.). The practices included: flat and raised planting beds; feather meal and fish emulsion fertilizer each applied at rates of 29 and $57 \mathrm{~kg} \cdot \mathrm{ha}^{-1}$ nitrogen (N); sawdust mulch, compost topped with sawdust mulch (compost + sawdust), or weed mat; and two cultivars, Duke and Liberty. Each treatment was irrigated by drip and weeds were controlled as needed. The planting was certified organic in 2008. After one growing season, allocation of biomass to the roots was greater when plants were grown on raised beds than on flat beds, mulched with organic mulch rather than a weed mat, and fertilized with the lower rate of $\mathbf{N}$. Plants also allocated more biomass belowground when fertilized with feather meal than with fish emulsion. Although fish emulsion improved growth relative to feather meal in the establishment year, this was not the case the next year when feather meal was applied earlier. After two seasons, total plant dry weight (DW) was generally greater on raised beds than on flat beds, but the difference varied depending on fertilizer and the type of mulch used. Shoots and leaves accounted for $60 \%$ to $77 \%$ of total plant biomass, whereas roots accounted for $7 \%$ to $19 \%$ and fruit accounted for $4 \%$ to $18 \%$. Plants produced $33 \%$ higher yield when grown on raised beds than on flat beds and had $36 \%$ higher yield with weed mat than with sawdust mulch. Yield was also higher when plants were fertilized with the low rate of fish emulsion than with any other fertilizer treatment in 'Duke' but was unaffected by fertilizer source or rate in 'Liberty'. Although raised beds and sawdust or sawdust + compost produced the largest total plant $\mathrm{DW}$, the greatest shoot growth and yield occurred when plants were mulched with weed mat or compost + sawdust on raised beds in both cultivars. The impact of these organic production practices on root development may affect the sustainability of these production systems over time, however, because plants with lower root-to-shoot ratios may be more sensitive to cultural or environmental stresses.
\end{abstract}

Received for publication 7 June 2013. Accepted for publication 9 Aug. 2013.

We recognize the financial support provided by the Oregon Blueberry Commission, the Northwest Center for Small Fruits Research, the Washington Blueberry Commission, the USDA National Institute of Food and Agriculture (Formula Grant no. OREI 2008-51300004443), and our industry contributors. We appreciate the valuable assistance of Emily Vollmer and Gil Buller at the NWREC, Oregon State University.

${ }^{1}$ Former MS graduate student, Department of Horticulture, Oregon State University. Present address: Driscoll Strawberry Associates, Inc., 1750 San Juan Road, Aromas, CA 95004.

${ }^{2}$ Professor and Extension Berry Crops Specialist. ${ }^{3}$ To whom reprint requests should be addressed; e-mail strikb@hort.oregonstate.edu. soils, reduce compaction, improve internal drainage (Magdoff and Van Es, 2000), and reduce disease problems such as Phytophthora root rot (Bryla and Linderman, 2007). Planting on flat ground, on the other hand, is thought to increase soil moisture and reduce soil temperature during the fruiting season, which is beneficial to root growth in southern highbush blueberry (complex hybrids based largely on $V$. corymbosum and $V$. darrowi Camp.) (Spiers, 1995).

Weed management is also critical for economic production in blueberry (Pritts and Hancock, 1992; Strik et al., 1993). Preemergent and contact herbicides are commonly used in conventional production systems, but chemical options are limited in organic systems. Acetic acid (vinegar) at a concentration of $9 \%$ to $20 \%$ has been effective at controlling some weeds organically (Fausey, 2003; Young, 2004). Propane flaming is used to control smaller weeds but may damage the plants, especially during establishment (Granatstein and Mullinix, 2008). Organic mulches are commonly used in blueberry to help control weeds (Burkhard et al., 2009; Krewer et al., 2009; Sciarappa et al., 2008), improve blueberry plant growth and yield (Clark and Moore, 1991; Goulart et al., 1997; Karp et al., 2006; Kozinski, 2006; Krewer et al., 2009; Savage, 1942; White, 2006), root distribution through the soil profile (Spiers, 2000), and whip and shoot production (Kozinski, 2006; White, 2006). Douglas-fir (Pseudotsuga menziesii M.) sawdust is a common mulch used in blueberry production in the northwestern United States, but it is expensive (Julian et al., 2011a) and the high initial carbon (C) to $\mathrm{N}$ ratio immobilizes $\mathrm{N}$ applied from fertilizers (White, 2006). It is often more difficult and more expensive to compensate for $\mathrm{N}$ immobilization with organic fertilizer products.

Weed mat (perforated landscape fabric) is considered an inert mulch (Granatstein and Mullinix, 2008) and is approved for use as a weed barrier by the USDA National Organic Program (USDA-AMS-NOP, 2011). Weed mat has been widely used in orchards as a result of its effectiveness for weed control, although weeds can grow in the area cut for the planting hole, and removal by hand may be required in commercial crops (Runham et al., 2000). Sciarappa et al. (2008) reported almost complete control of weeds when using weed mat plus a mulch of coffee grinds around the planting area in organic blueberry production in New Jersey. However, soil temperature may increase under the weed mat and thereby reduce plant growth (Neilsen et al., 2003; Williamson et al., 2006). Magee and Spiers (1995) found that white-on-black polyethylene-based mulches produced greater plant growth and yield than black plastic or black woven fabric mulches in southern highbush cultivars as a result of decreased soil temperature under the more reflective mulches. In Georgia, rabbiteye blueberry ( $V$. virgatum Ait.) established with organic mulches had similar yields to those with weed mat in the first 2 years of establishment 
but greater yield in Years 3 to 5 (Krewer et al., 2009).

Compost may provide many benefits to blueberry production. As compost decomposes, it releases $\approx 3 \%$ to $10 \%$ of total $\mathrm{N}$ as mineral $\mathrm{N}$ for several years after the initial application (Gale et al., 2006; Sikora and Szmidt, 2001). Burkhard et al. (2009) found greater growth and yield of highbush blueberry when using seafood compost and manuresawdust compost. Municipal yard debris compost is readily available in many production regions and may be suitable for commercial blueberry production (Costello, 2011).

Highbush blueberry requires $\mathrm{N}$ fertilizer at a rate of $\approx 25$ to $100 \mathrm{~kg} \cdot \mathrm{ha}^{-1} \mathrm{~N}$ per year for optimum growth and production (Bañados et al., 2012; Chandler and Mason, 1942; Eck, 1988; Griggs and Rollins, 1947; Hanson, 2006; Hart et al., 2006). Uptake of $\mathrm{N}$ fertilizer is most rapid from bloom to harvest (Bañados, 2006; Throop and Hanson, 1997) but continues through the remainder of the growing season (Bañados, 2006). In 'Bluecrop', fertilizing with ammonium sulfate (50 $\mathrm{kg} \cdot \mathrm{ha}^{-1} \mathrm{~N}$ ) produced more growth and fruit production during the first 2 years after planting than unfertilized plants or rates of 100 or $150 \mathrm{~kg} \cdot \mathrm{ha}^{-1} \mathrm{~N}$ (Bañados et al., 2012). Nitrogen fertilization with different rates of ammonium sulfate also affected biomass accumulation and allocation (Bañados et al., 2012); however, the impact of organic fertilizers on blueberry growth and allocation has not been reported.

Organic blueberry farmers commonly use fertilizer products approved by the Organic Materials Review Institute, including fish emulsion or feather meal as sources of $\mathrm{N}$. Fish emulsion is applied as a direct liquid application to the soil of the in-row area or is injected through the drip irrigation system. Feather meal, a granular product, has a very rapid $\mathrm{N}$ mineralization rate, converting $30 \%$ to $60 \%$ of its total $\mathrm{N}$ to mineral $\mathrm{N}$ in $14 \mathrm{~d}$ in moist soil with cumulative mineral $\mathrm{N}$ release of $65 \%$ to $75 \%$ of total $\mathrm{N}$ after $70 \mathrm{~d}$ (Gale et al., 2006). Fish fertilizer products also mineralize $\mathrm{N}$ rapidly after application to soil. Sullivan et al. (2010) reported equivalent $\mathrm{N}$ mineralization rates $(58 \%$ to $64 \%$ of total $\mathrm{N}$ converted to mineral $\mathrm{N}$ in $28 \mathrm{~d}$ ) for a variety of fish and feather meal fertilizers.

The objective of the present study was to evaluate the effects of using flat or raised planting beds, three different mulch types, and feather meal or fish emulsion fertilizer on plant growth and early production in a new organic planting of northern highbush blueberry.

\section{Materials and Methods}

Study site. A 0.43-ha field of northern highbush blueberry (Vaccinium corymbosum L.) was established in Oct. 2006 on a site in transition to organic production at the North Willamette Research and Extension Center (NWREC; lat. 45 $16^{\prime} 47.55^{\prime \prime} \mathrm{N}$, long. $122^{\circ} 45^{\prime} 21.90^{\prime \prime} \mathrm{W}$ ), Aurora, OR. Winter wheat (Triticum sp.) was planted in the field for at least 10 years before the study. Soil at the site is a Willamette silt loam (fine-silty mixed superactive mesic Pachic Ultic Argixeroll). Organic matter content in the soil averaged $3.7 \%$ at planting, and soil $\mathrm{pH}$ averaged 4.9. The planting was certified organic by Oregon Tilth (OTCO; Salem, OR) in May 2008.

Site preparation. Buckwheat (Fagopyrun esculentum M.) was seeded at a rate of 67 $\mathrm{kg} \cdot \mathrm{ha}^{-1}$ on 30 May 2006, as a pre-plant cover crop, and was incorporated into the soil, before seed head formation, on 26 July 2006. Rows were marked and were sub-soiled once using a three-shank ripper to a depth of $\approx 0.4 \mathrm{~m}$ followed by three passes with a singleshank ripper to a depth of $\approx 0.5 \mathrm{~m}$. Rows were then power-spaded in early September while the soil was still dry. The site was irrigated until the wetting front was $\approx 0.3 \mathrm{~m}$ deep. A few days later, when the soil was dry, the rows were rototilled to a depth of $0.15 \mathrm{~m}$ before using a bed shaper (depending on treatment). Raised beds were $0.31 \mathrm{~m}$ high and $0.38 \mathrm{~m}$ wide at the top and $1.5 \mathrm{~m}$ wide at the base when established but settled to a height of $\approx 0.25 \mathrm{~m}$ by Fall 2007 .

Certified organic grass (Festulolium braunii K.Richt.) was seeded between rows at a rate of $28 \mathrm{~kg} \cdot \mathrm{ha}^{-1}$ on 14 Oct. 2006 , a standard commercial practice. The between-rowcover crop was kept from encroaching into the rows by spraying the edges with $20 \%$ vinegar (acetic acid) solution generally every 3 weeks during the growing season or by edging it using a power string trimmer.

Experimental design. Treatments were arranged in a split-split plot design and included two bed types (one row as a raised bed and one row on flat ground, referred to as a flat bed) as main plots, two types and rates of fertilizer [feather meal (Nature Safe, Cold Spring, KY) and fish emulsion (Fish Agra, Northeast Organics Inc., Manchester-by-theSea, MA) each applied at a rate of 29 and 57 $\mathrm{kg} \cdot \mathrm{ha}^{-1} \mathrm{~N}$ ] as subplots, and a combination of three mulch types [douglas fir (Pseudotsuga menziesii M.) sawdust; yard debris compost topped with douglas fir sawdust; and weed mat (landscape fabric) with douglas fir sawdust applied over the planting hole cut in the weed mat] and two cultivars (Duke and Liberty) as sub-subplots with five replicates per treatment and seven plants per treatment plot. Plants were spaced $0.75 \mathrm{~m}$ apart within plots and $1.5 \mathrm{~m}$ apart between plots. The planting had a total of 12 rows spaced $3.0 \mathrm{~m}$ apart and included a border row on each side
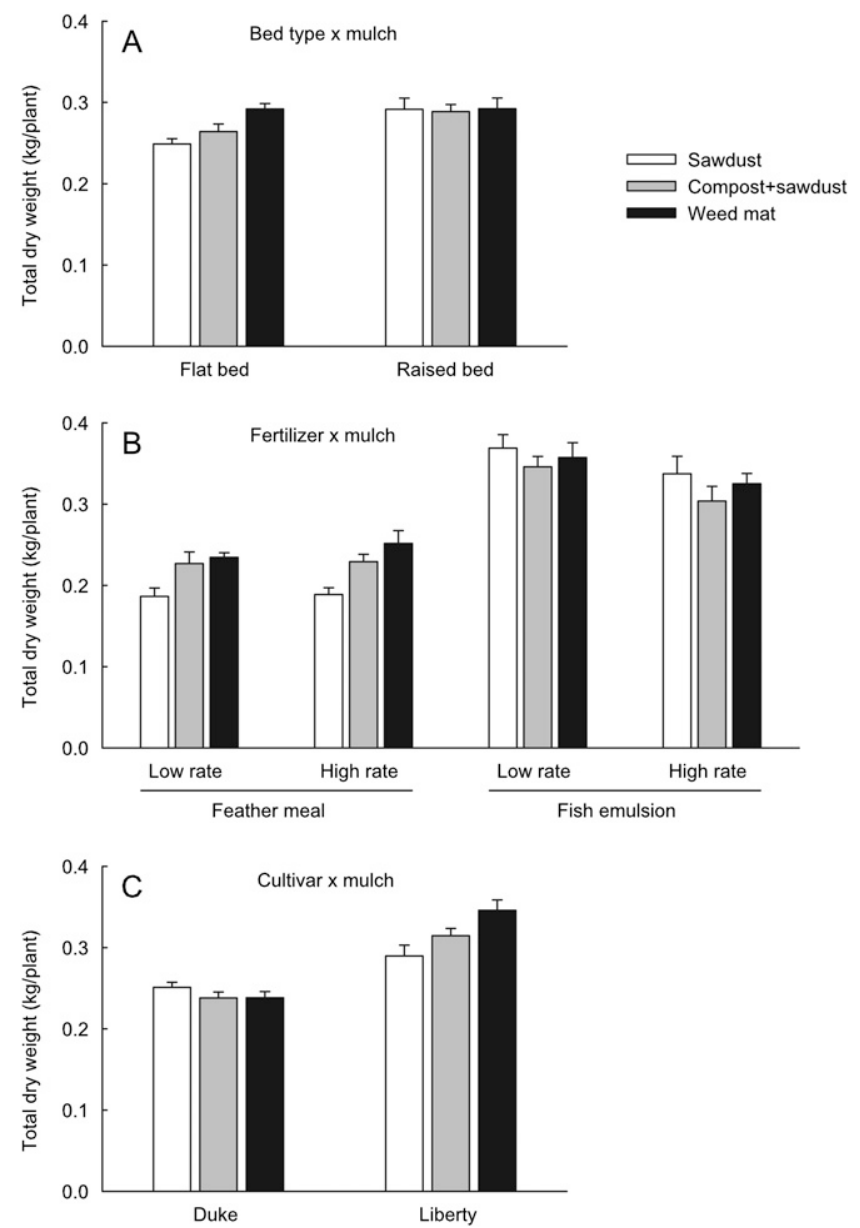

Fig. 1. Interaction effects of bed type and mulch (A), fertilizer and mulch $(\mathbf{B})$, and cultivar and mulch $(\mathbf{C})$ on total dry weight of 'Duke' and 'Liberty' blueberry after the first growing season. The plants were grown on flat and raised planting beds mulched with sawdust, compost topped with sawdust, or weed mat and were fertilized with feather meal or fish emulsion at low or high rates with 29 and $59 \mathrm{~kg} \cdot \mathrm{ha}^{-1}$ nitrogen $(\mathrm{N})$, respectively. Mean \pm SE. 
(4385 plants/ha). Two-year-old container grown (4 L) plants, a standard commercial size, were transplanted on 9 Oct. 2006.

The sawdust mulch was applied $9 \mathrm{~cm}$ deep $\left(360 \mathrm{~m}^{3} \cdot \mathrm{ha}^{-1}\right.$; Decorative Bark, Lyons, OR). Any weeds occurring in this mulch were pulled by hand throughout the study. Black weed mat (landscape fabric; water flow rate of $6.8 \mathrm{~L} \cdot \mathrm{h} \cdot \mathrm{m}^{-2} ; 0.11 \mathrm{~kg} \cdot \mathrm{m}^{-2}$; TenCate Protective Fabrics, OBC Northwest, Inc., Canby, OR) made from woven polypropylene was installed with sawdust mulch covering the 20 -cm diameter planting hole area $(5 \mathrm{~cm}$ deep; $\left.7 \mathrm{~m}^{3} \cdot \mathrm{ha}^{-1}\right)$. Any weeds occurring around the crown area of the plants with weed mat were also pulled by hand. The compost + sawdust mulch included a yard debris compost $(4 \mathrm{~cm}$ deep; $152 \mathrm{~m}^{3} \cdot \mathrm{ha}^{-1}$; Rexius, Eugene, OR) topped with sawdust ( $5 \mathrm{~cm}$ deep; $200 \mathrm{~m}^{3} \cdot \mathrm{ha}^{-1}$ ). Weeds were controlled in the compost + sawdust treatment using vinegar $(20 \%$ acetic acid), propane flaming, and hand-pulling as needed. Vinegar applications were done after $1000 \mathrm{HR}$ on days with no rain and limited wind in 2007-08 (Webber et al., 2005). A handheld propane flamer was constructed with a $0.20-\mathrm{m}$ diameter head and a 860,000 to $1,505,000 \mathrm{~kg} \cdot \mathrm{m}^{-1}$ small gas heater attached to a rod to facilitate spot burning in 2008. In all mulch treatments, the complementary weed control methods were applied if the visual evaluation of weed coverage was greater than $20 \%$ in several plots to avoid confounding weed competition with blueberry plants and mulch effects. Costs of weed control methods and associated treatment effects are presented in Julian et al. (2012).

The compost and sawdust mulches were applied $3 \mathrm{~d}$ after planting on 12 Oct. 2006 and did not require replenishment during this study period (through 2008). The weed mat was $1.5 \mathrm{~m}$ wide and centered over the planting beds before securing it with landscape staples. The sawdust mulch, soil, and yard debris compost were analyzed for nutrient composition at the beginning of the study (Soil Control Laboratory, Watsonville, CA), as presented by Larco (2010).

Feather meal (Nature Safe, Cold Spring, $\mathrm{KY} ; 11 \mathrm{~N}-0.6 \mathrm{P}-0.1 \mathrm{~K}$ ), a granular product, was applied around the base of the plants in two equal applications on 3 Apr. and 16 May in 2007 and 4 Mar. and 22 Apr. in 2008 (plants started to flower in mid-April). Fish emulsion (Fish Agra; Northeast Organics, Manchester-by-the-Sea, MA; 3.6N-0.6P$5.2 \mathrm{~K}$ ) was also applied around the base of the plants, but every 2 weeks from 16 Apr. to 9 July in 2007 and 15 Apr. to 8 July in 2008 . To reduce risk of salt damage to the plants, fish emulsion was diluted with 10 parts water before each application. Plants fertilized with feather meal were $\mathrm{N}$-deficient during the first summer after planting as determined by visual observation and leaf analysis (Larco, 2010) and, therefore, were fertilized with an additional $4 \mathrm{~kg} \cdot \mathrm{ha}^{-1} \mathrm{~N}$ of fish emulsion on 28 June and 5 July 2007. The plants ceased to show N deficiency symptoms and leaf analysis results were normal for all treatments by Aug. 2007 (data not shown); the feather meal treatment thus did not require fish emulsion in subsequent years.

Field management. Plants were irrigated using a single line of polyethylene drip tubing (Netafim, Fresno, CA). The tubing had $2 \mathrm{~L} \cdot \mathrm{h}^{-1}$ pressure-compensating, inline emitters spaced every $0.3 \mathrm{~m}$. Lines were located along the row near the base of plants and either placed beneath the weed mat or buried under the organic mulches (for consistency among mulch treatments). A second line of drip (located near the base of the plants but on the other side of the row of the first line) was also installed right after planting in weed mat plots in anticipation of possible requirements for additional irrigation to compensate for increased water use associated with higher temperatures in the treatment (Cox, 2009; Neilsen et al., 2003; Williamson et al., 2006). Irrigation was controlled by electric solenoid valves and an automatic timer set weekly and scheduled based on changes in soil water content (see Larco, 2010, for details). Rows planted on raised beds or flat ground (main plot effect) could be irrigated independently as could weed mat compared with the organic mulches. All treatment plots were irrigated to maintain a soil water content suitable for highbush blueberry production [25\% to $30 \%$ soil water content from the soil surface to 0.3 $\mathrm{m}$, based on time domain reflectometry measurements (SoilMoisture Equip. Corp., Santa Barbara, CA)]. Water volume applied through the season was recorded (data not shown; Larco, 2010).

To maximize vegetative growth during the establishment year, plants were pruned to remove all fruit buds at planting (Strik and Buller, 2005), a standard commercial practice. In Jan. 2008, after the first growing season, plants were pruned to allow for fruit production in the second growing season, also a standard commercial practice (Julian et al., 2011a), to balance vegetative growth with expected fruit production. 'Duke' were harvested from 3 July to 23 July and 'Liberty' from 23 July to 13 Aug. 2008. Fruit were harvested by hand every 5 to $7 \mathrm{~d}$ and yield per plant was measured. A 25-berry subsample per harvest date was used to determine
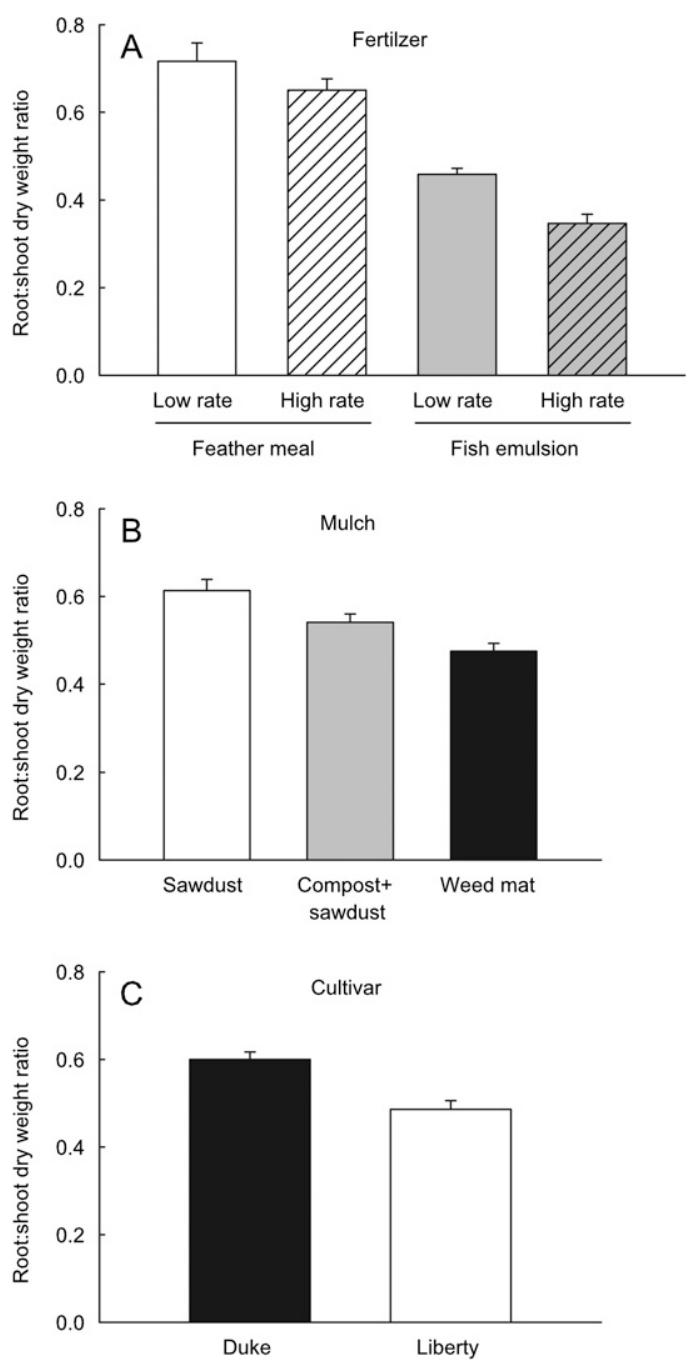

Fig. 2. Main effects of fertilizer (A), mulch (B), and cultivar (C) on dry weight ratio of roots (including the crown) to shoots (woody stems) in 'Duke' and 'Liberty' blueberry after the first growing season. The plants were grown on flat and raised planting beds mulched with sawdust, compost topped with sawdust, or weed mat and were fertilized with feather meal or fish emulsion at low or high rates with 29 and $59 \mathrm{~kg} \cdot \mathrm{ha}^{-1}$ nitrogen $(\mathrm{N})$, respectively. Mean $\pm \mathrm{SE}$. 
Table 1. The main effect of fertilizer source and rate and mulch type on the allocation of dry weight of 'Duke' and 'Liberty' highbush blueberry on 2 Oct. 2007 , after the first growing season.

\begin{tabular}{|c|c|c|c|c|c|c|c|c|c|}
\hline \multirow{2}{*}{\multicolumn{2}{|c|}{ Treatment }} & \multicolumn{8}{|c|}{ Allocation of dry wt based on annual growth $(\%)^{y}$} \\
\hline & & \multicolumn{4}{|c|}{ Duke } & \multicolumn{4}{|c|}{$\begin{array}{l}\text { Liberty } \\
\end{array}$} \\
\hline$\overline{\text { Fertilizer rate/source }}{ }^{z}$ & Mulch type & Roots & Crown & 1-year-old wood & Leaves & Roots & Crown & 1-year-old wood & $\overline{\text { Leaves }}$ \\
\hline Low fish & & 7 & 15 & 43 & 34 & 4 & 14 & 48 & 33 \\
\hline High fish & & 4 & 12 & 46 & 37 & 3 & 11 & 49 & 37 \\
\hline Low feather & & 11 & 24 & 41 & 24 & 7 & 21 & 45 & 28 \\
\hline \multirow[t]{4}{*}{ High feather } & & 10 & 21 & 43 & 26 & 7 & 21 & 45 & 27 \\
\hline & Sawdust + compost & 9 & 19 & 44 & 29 & 4 & 17 & 47 & 31 \\
\hline & Sawdust & 9 & 20 & 41 & 30 & 6 & 18 & 45 & 31 \\
\hline & Weed mat & 7 & 15 & 45 & 32 & 5 & 15 & 48 & 32 \\
\hline
\end{tabular}

Significance ${ }^{\mathrm{x}}$

$\begin{array}{lrrrr}\text { Bed type (A) } & 0.0504 & 0.2005 & 0.1695 & 0.3721 \\ \text { Fertilizer (B) } & <\mathbf{0 . 0 0 0 1} & <\mathbf{0 . 0 0 0 1} & \mathbf{0 . 0 0 0 5} & <\mathbf{0 . 0 0 0 1} \\ \text { Mulch (C) } & \mathbf{0 . 0 0 8 8} & <\mathbf{0 . 0 0 0 1} & <\mathbf{0 . 0 0 0 1} & \mathbf{0 . 0 0 0 3} \\ \text { Cultivar (D) } & <\mathbf{0 . 0 0 0 1} & 0.0810 & <\mathbf{0 . 0 0 0 1} & \mathbf{0 . 0 2 0 7} \\ \text { A } \times \text { B } & 0.1563 & 0.1286 & 0.2029 & 0.0675 \\ \text { A } \times \text { C } & 0.7685 & 0.0641 & 0.1456 & 0.5361 \\ \text { A } \times \text { D } & 0.6024 & 0.4933 & 0.7571 & 0.8927 \\ \text { B } \times \text { C } & 0.6170 & 0.7705 & 0.8766 & 0.5252 \\ \text { B } \times \text { D } & \mathbf{0 . 0 0 6 8} & 0.2700 & 0.3068 & \mathbf{0 . 0 0 0 4} \\ \text { C } \times \text { D } & 0.0921 & 0.6570 & 0.9729 & \mathbf{0 . 0 0 6 9} \\ \text { A } \times \text { B } \times \text { C } & 0.4831 & 0.6819 & 0.4819 & 0.7474 \\ \text { A } \times \text { B } \times \text { D } & 0.9214 & 0.5370 & 0.8334 & 0.7004 \\ \text { A } \times \text { C } \times \text { D } & 0.4417 & 0.5979 & 0.1931 & 0.8701 \\ \text { B } \times \text { C } \times \text { D } & 0.2646 & 0.2144 & 0.2318 & 0.1014 \\ \text { A } \times \text { B } \times \text { C } \times \text { D } & 0.9099 & 0.9435 & 0.9989 & 0.8226 \\ \text { Contrasts } & & & & \\ \text { Fertilizer source } & <\mathbf{0 . 0 0 0 1} & <\mathbf{0 . 0 0 0 1} & \mathbf{0 . 0 1 9 3} & <\mathbf{0 . 0 0 0 1} \\ \text { Fertilizer rate } & \mathbf{0 . 0 0 8 0} & \mathbf{0 . 0 0 2 1} & 0.2848 & <\mathbf{0 . 0 0 0 1} \\ \text { Weed mat vs. organic mulches } & \mathbf{0 . 0 0 7 9} & <\mathbf{0 . 0 0 0 1} & \mathbf{0 . 0 0 1 4} & \mathbf{0 . 0 0 0 2} \\ \text { Sawdust vs. compost } & 0.1142 & 0.0874 & 0.0003 & 0.0768\end{array}$

${ }^{2}$ Fish emulsion and feather meal were applied at a low $\left(29 \mathrm{~kg} \cdot \mathrm{ha}^{-1} \mathrm{~N}\right)$ or high $\left(57 \mathrm{~kg} \cdot \mathrm{ha}{ }^{-1} \mathrm{~N}\right)$ rate.

${ }^{y}$ Annual growth was calculated as the sum of the DW of 1-year-old wood (current season's shoots), leaves, crown and roots (DW in Oct. 2007 - DW

of nursery plant Oct. 2006). Percent allocation was calculated as the portion of the plant part indicated of the total annual growth.

${ }^{x}$ Bold font is used to designate values with $P<0.05$.

$\mathrm{N}=$ nitrogen; DW = dry weight.

average berry weight and a seasonal-weighted average calculated.

Plant growth. In Fall 2007 and 2008, the number of whips/plant (greater than $0.1 \mathrm{~m}$ in height and greater than $3 \mathrm{~mm}$ in diameter) was recorded. The area covered by the plant canopy was calculated by measuring plant diameter in two directions and calculating the area of the circle. On 2 Oct. 2007 and 17 Oct. 2008, a single plant per plot was excavated from the soil with a shovel, carefully, to obtain as much of the root system as possible. Soil was removed from the root system using a high-pressure hose and tap water. Plants were separated into roots, crown, leaves, and 1-year and older wood in 2007 and 1-year-old and 2-year and older wood in 2008. Leaves were stored at $2{ }^{\circ} \mathrm{C}$ for less than $7 \mathrm{~d}$ before measurement of total leaf area per plant (LI3100 leaf area meter; LI-COR, Lincoln, NE). Leaf area index (LAI) was calculated as the ratio of the total leaf area per plant divided by the calculated area occupied by the plant canopy of the plant (measured before excavation). Plant parts were placed in labeled paper bags and dried to a constant weight $(\approx 3 \mathrm{~d})$ at $60^{\circ} \mathrm{C}$ using a dryer oven (Fisher Scientific Isotemp oven Model 655F; Montreal, Quebec, Canada).

Total plant dry weight (DW; sum of all plant components), root:shoot ratio [(root DW + crown DW)/DW of all top wood growth without leaves], and the percentage of total DW accounted for by roots, crown, 1-year, 2-year, and older wood were calculated for "standing" plant DW in October of each year, just before leaf fall and before winter pruning. The proportion of biomass allocation to roots, crown, wood, and leaves was calculated to determine "standing biomass allocation" in October of each year. In 2008, the DW of fruit produced was estimated by multiplying fresh yield by $18 \%$ (Strik, unpublished data). Biomass allocation to reproductive growth was calculated by either adding fruit DW to the standing DW total and determining percent allocation of plant parts ("percentage of standing biomass") or by determining the annual growth and the percent allocation to fruit ("percentage of annual production") based on Pritts and Hancock (1985). Annual growth in 2008 was calculated by summing the DW of parts that grew in 2008 (1-year-old wood, leaves, and fruit) and the increase in crown and root DW from Oct. 2007 to 2008; the proportion of annual DW accumulation allocated to roots, crown, wood, leaves, and fruit (2008) was calculated as the "annual biomass allocation." Because plants were pruned in Jan. 2008 and data on pruning weight were not collected, we could not calculate total growth by subtracting total plant DW in 2007 from total plant DW in 2008.

Statistical analysis. Analysis of all treatment effects on plant growth and allocation of DW was done as a complete factorial for a split-split plot design using the PROC MIXED procedure in SAS software package Version 8 (SAS Institute, Cary, NC). Contrasts were used to compare the effect of fertilizer rate and source and compost type on measured variables. Results for both years were analyzed separately because of differences in plant age in the field and environmental differences between years. Data were log-transformed as needed to improve homogeneity of variance. Orthogonal contrasts were used to compare source (fish vs. feather) and rate (low vs. high) of fertilizer and type of mulch ["organic" (sawdust and compost + sawdust) vs. weed mat; and sawdust vs. compost + sawdust]. Means were separated at 0.05 level using Tukey's honestly significant difference test. The PROC CORR procedure in SAS was used to determine whether the DW of 1-yearold wood in Fall 2007 was correlated with the DW of fruit produced in 2008.

\section{Results}

Plant growth (Year 1). At the end of the first growing season, total plant DW was affected by bed type $(P=0.0143)$, fertilizer $(P<0.0001)$, mulch $(P=0.0158)$, and cultivar $(P<0.0001)$ as well as by the twoway interactions of bed type $\times$ mulch $(P=$ $0.0482)$, fertilizer $\times$ mulch $(P=0.0002)$, and 
mulch $\times$ cultivar $(P=0.0067)$. On average, total plant DW was greater with weed mat than with sawdust or compost + sawdust on flat beds but similar among mulch treatments on raised beds (Fig. 1A). Total plant DW was also greater with weed mat than with sawdust when: 1) plants were fertilized with feather meal but not with fish emulsion (Fig. 1B); and 2) in 'Liberty' but not in 'Duke' (Fig. 1C). Fish emulsion produced 55\% more plant DW than feather meal in Year $1(P<0.0001)$, but plant DW was unaffected by the rate of fertilizer application $(P=0.1604)$.

There was no effect of bed type or mulch on root and crown DW. Greater total plant DW of plants grown on raised beds compared with flat beds was mainly the result of more shoot $(P=0.0010)$ and leaf $(P=0.0217)$ growth in the first growing season (data not shown). Although mulch had little impact on total shoot or leaf DW when plants were grown on raised beds, plants mulched with sawdust or compost + sawdust had $16 \%$ to $18 \%$ less leaf and shoot DW when grown on flat beds $(P=0.0391$ and $P=0.0231$, respectively; data not shown).

Fertilizer source had a significant impact on shoot $(P<0.0001)$ and leaf $(P<0.0001)$ DW but not on root and crown DW. In contrast, fertilizer rate affected crown $(P=0.0003)$ and root $(P=0.0053)$ DW. Plants fertilized with fish emulsion had more than twice the leaf DW and 60\% more 1-year-old wood DW than those fertilized with feather meal. Crown and root DW were $20 \%$ to $22 \%$ greater for plants fertilized with the low rate than those fertilized with the higher rate of fish or feather meal (data not shown).

Plants fertilized with feather meal had $28 \%$ to $31 \%$ less shoot and leaf DW than plants fertilized with fish emulsion when grown with sawdust mulch. In contrast, there was no effect of fertilizer source on shoot and leaf DW when plants were mulched with weed mat. Root DW was less under weed mat than under sawdust mulch when fertilized with the low rate of fish emulsion (data not shown).

On average, 'Liberty' plants produced greater crown $(P<0.0001)$, shoot $(P<$ $0.0001)$, and leaf $(P<0.0001)$ DW but less root DW $(P=0.0013)$ than 'Duke' plants (data not shown). There was a mulch $\times$ cultivar interaction because 'Liberty' plants produced greater top growth (leaves and 1-year-old wood) when mulched with weed mat than with the organic mulches, but there was relatively little effect of mulch type on top growth of 'Duke'. When 'Duke' plants were grown on weed mat, they produced less root growth than when organic mulches were used; this was not the case in 'Liberty' (data not shown).

Standing biomass allocation at the end of the first growing season showed that biomass allocation to roots was greater when plants were grown on raised beds $(10 \%)$ than on flat beds $(9 \%)$, when fertilized with feather meal $(12 \%)$ as compared with fish emulsion $(7 \%)$, and for 'Duke' (11\%) compared with 'Liberty' ( $8 \%$ ) (data not shown). These differences were reflected in the ratio between root and shoot dry weight, which was affected by fertilizer $(P<0.0001)$, mulch $(P<0.0001)$, and cultivar $(P<0.0001)$. The root-to-shoot ratio was higher with feather meal than with fish emulsion (Fig. 2A), higher with sawdust or compost + sawdust than with weed mat (Fig. 2B), and higher in 'Duke' than in 'Liberty' (Fig. 2C). Contrast analysis indicated that the ratio was also higher when lower rates of fertilizer were applied $(P=0.0002)$.

After the first growing season, annual biomass allocation based on growth or accumulation of dry matter was affected by fertilizer and mulch for each plant part and by cultivar except for the crown (Table 1). Annual biomass allocation was also affected by several treatment interactions, including fertilizer $\times$ cultivar for root growth and fertilizer $\times$ cultivar and mulch $\times$ cultivar for leaf growth. Both cultivars allocated more biomass to root and crown tissue and less to wood and leaves when fertilized with feather meal than when fertilized with fish emulsion and more biomass to wood and leaves and less to roots and crown when mulched with weed mat compared with either organic mulch (Table 1).

The treatment effects on leaf area per plant in Fall 2007 were similar to those reported for leaf DW; leaf area ranged from $1.2 \mathrm{~m}^{2}$ (low rate of feather meal) to $1.9 \mathrm{~m}^{2}$ (high rate of fish). There was no treatment effect on LAI, which ranged from 1.6 to 1.8 (data not shown).

The number of whips per plant was affected by mulch $(P=0.0002)$ and cultivar $(P<0.0001)$ and the two-way interactions of bed type $\times$ fertilizer $(P=0.0026)$, bed type $\times$ mulch $(P=0.0328)$, and mulch $\times$ cultivar $(P=0.0184)$. Plants fertilized with feather meal produced fewer whips/plant at the low rate when grown on raised beds and at the high rate when ground on flat beds (Fig. 3A). Mulching with weed mat led to fewer whips/ plant than with the organic mulches, particularly when plants were grown on raised beds (Fig. 3B). 'Liberty' produced more whips/ plant than 'Duke' and when mulched with compost + sawdust (Fig. 3C).

Plant growth (Year 2). Total plant DW was also affected by bed type $(P<0.0001)$, fertilizer $(P<0.0121)$, and cultivar $(P<0.0001)$ during after the second growing season and by two-way and three-way interactions, including fertilizer $\times$ mulch $(P=0.0008)$, fertilizer $\times$ cultivar $(P=0.0066)$, bed type $\times$ fertilizer $\times$ mulch $(P=0.0421)$, and fertilizer $\times$ mulch $\times$ cultivar $(P=0.0054)$. Total plant DW in Year 2 was generally greater on raised beds than on flat beds but the difference varied depending on fertilizer and the type of mulch used (Fig. 4A). For example, when plants were fertilized
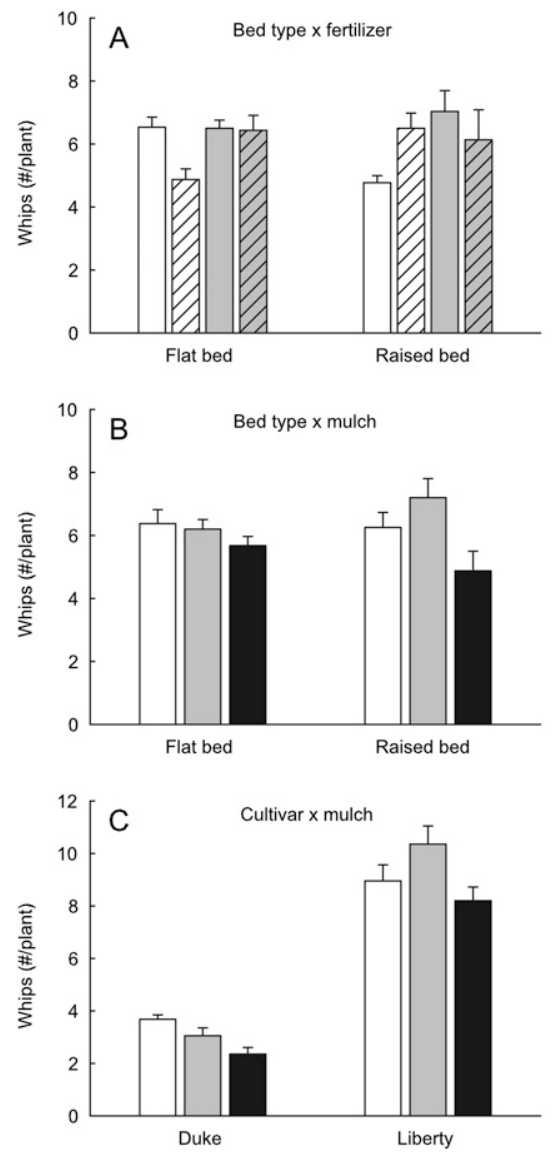

Fig. 3. Interaction effects of bed type and fertilizer (A), bed type and mulch (B), and cultivar and mulch $(\mathbf{C})$ on new whips per plant in 'Duke' and 'Liberty' blueberry after the first growing season. The plants were grown on flat and raised planting beds mulched with sawdust, compost topped with sawdust, or weed mat and were fertilized with feather meal or fish emulsion at low or high rates with 29 and $59 \mathrm{~kg} \cdot \mathrm{ha}^{-1}$ nitrogen $(\mathrm{N})$, respectively. Mean $\pm \mathrm{SE}$. 
with a high rate of feather meal, total DW was greater on raised beds than on flat beds with any mulch, but when plants were fertilized with a high rate of fish emulsion, total DW was only greater on raised beds when the beds were mulched with sawdust. Overall, the largest plants were produced on raised beds fertilized with a low rate of fish emulsion and mulched with sawdust or compost + sawdust (Fig. 4A). The response to fertilizer and mulch also differed between cultivars at the end of the second growing season, whereby sawdust mulch and a low rate of fish fertilizer produced the greatest plant DW in 'Duke', whereas sawdust or compost + sawdust with a high or low rate of fish, respectively, produced the greatest total DW in 'Liberty' (Fig. 4B).

After two growing seasons (Oct. 2008), the treatment effects on growth of plant parts were similar to those observed the first year with some notable exceptions. Although there was no three-way interaction of fertilizer $x$ mulch $\times$ cultivar in 2007 , there was one in 2008 for leaf, 1-year-old wood, crown, and root DW. Also, root and crown DW was affected by mulch type by the end of the second growing season. Fertilizer had no effect on 1-year-old wood DW (new shoot growth) in Oct. 2008, but fertilizer source had an effect on 2-year-old wood DW (Table 2).

Plants fertilized with fish emulsion had the greatest root DW when mulched with compost + sawdust and the least when mulched with weed mat. In contrast, those fertilized with the high rate of feather meal had the greatest root DW under weed mat (Table 2). The greatest root DW in 'Duke' was found in plants fertilized with the low rate of fish emulsion and mulched with sawdust, whereas this treatment combination produced one of the lowest root DWs in 'Liberty'. 'Duke' plants had the least root growth when mulched with weed mat and fertilized with the high rate of fish.

Crown DW was lower for plants mulched with weed mat than with sawdust or compost + sawdust. Also, when weed mat was used, crown DW was reduced when plants were fertilized with fish emulsion, especially at the high rate, as compared with feather meal (Table 2). In 'Liberty', one of the greatest crown DWs was found in plants fertilized with the high rate of fish and mulched with sawdust; in contrast, this treatment combination produced one of the lowest crown DWs in 'Duke'.

After the second growing season, plants growing on raised beds still produced more new growth (1-year-wood and leaf DW) than those grown on flat beds (Table 2). In 'Liberty', the greatest new top growth was found in plants mulched with sawdust and fertilized with the high rate of fish emulsion and the least in the weed mat plus low rate of fish emulsion treatment combination. In 'Duke', there was less difference among treatments for top growth, but plants grown with sawdust mulch and fertilized with the low rate of fish tended to have the greatest top DW, whereas those grown with weed mat and fertilized with the high rate of fish had the least.
At the end of the second growing season, 'Liberty' allocated proportionally less standing biomass to roots $(12 \%)$, but more to the crown (13\%) and 1-year-old wood (18\%) than did 'Duke' (14\%, $10 \%$, and $17 \%$, respectively).

The treatment effects on leaf area per plant in Fall 2008 were similar to those reported for leaf DW (Table 2); leaf area was affected by bed type $(P=0.0022)$, mulch $(P<0.0001)$, fertilizer $(P=0.0051)$, fertilizer source $(P<0.0001)$, fertilizer rate $(P=0.0064)$, and cultivar $(P=0.0011)$ and the interactions of bed type $\times$ mulch $(P=0.0113)$, fertilizer $\times$ mulch $(P=0.0051)$, and fertilizer $\times$ mulch $\times$ cultivar $(P=0.0439)$ and ranged from 1.0 to 3.0 $\mathrm{m}^{2} /$ plant.

Unlike the first growing season, there was a significant effect of bed type $(P=0.0115)$ and fertilizer source $(P<0.0001)$ and the three-way interaction of bed type $\times$ fertilizer $x$ mulch $(P=0.0249)$ on LAI. Leaf area index almost doubled from the first to the second growing season, averaging 3.2 in Oct. 2008.

The number of whips/plant in the second growing season was similar to what was observed in 2007 and was affected by fertilizer $(P=0.0010)$, fertilizer source $(P<$ $0.0001)$, mulch $(P=0.0033)$, and cultivar $(P<0.0001)$ and the two-way interaction of fertilizer $\times$ cultivar $(P=0.0276)$. Although 'Duke' plants produced a similar number of whips/plant regardless of fertilizer source,
'Liberty' produced the highest number of whips/plant when fertilized with feather meal and the lowest with fish emulsion (Fig. 5A). Plants mulched with weed mat produced fewer whips/plant than those mulched with sawdust or compost + sawdust (Fig. 5B).

Early fruit production. Total yield during the first year of fruit production in 2008 was affected by bed type $(P=0.0163)$, fertilizer $(P<0.0001)$, mulch $(P<0.0001)$, cultivar $(P<0.0001)$, and the interaction between cultivar and fertilizer $(P<0.0001)$. On average, plants produced $33 \%$ higher yields on raised beds than on flat beds (Fig. 6A). 'Duke' also produced higher yields with a low rate of fish emulsion than with any other fertilizer treatment; however, yield was not significantly affected by fertilizer source or rate in 'Liberty' (Fig. 6B). Plants also produced 36\% higher yield with weed mat than with sawdust mulch (Fig. 6C). The DW of 1-year-old wood/ plant in Oct. 2007 was correlated with fruit $\mathrm{DW} /$ plant in 2008 (data not shown; $r^{2}=0.413$; $P<0.0001)$.

Fruit were large at harvest and, depending on treatment, had an average weight of 1.9 to $2.3 \mathrm{~g} /$ berry. Berry weight was affected by bed type $(P=0.0018)$, fertilizer $(P=0.0069)$, and cultivar $(P<0.0001)$ and several two-way interactions, including fertilizer $\times$ mulch $(P=$ $0.0336)$, fertilizer $\times$ cultivar $(P=0.0026)$, and mulch $\times$ cultivar $(P<0.0001)$. Plants generally
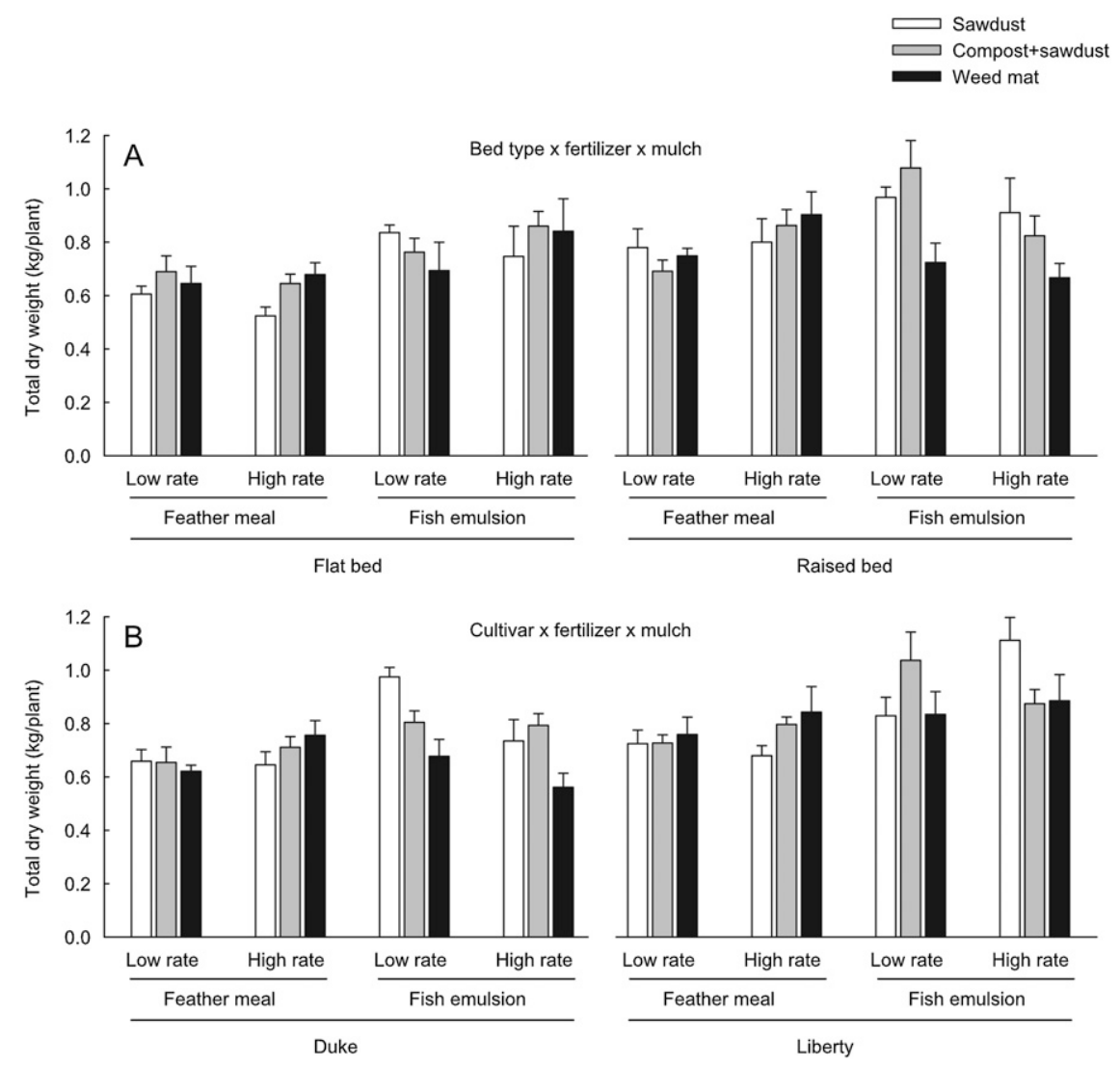

Fig. 4. Interaction effects of bed type, fertilizer, and mulch (A) and cultivar, fertilizer, and mulch (B) on total dry weight of 'Duke' and 'Liberty' blueberry after the second growing season. The plants were grown on flat and raised planting beds mulched with sawdust, compost topped with sawdust, or weed mat and were fertilized with feather meal or fish emulsion at low or high rates with 29 and $59 \mathrm{~kg} \cdot \mathrm{ha}^{-1}$ nitrogen $(\mathrm{N})$, respectively. Mean $\pm \mathrm{SE}$. 
Table 2. The effect of bed type, mulch, and fertilizer source and rate on the dry weight of plant parts of 'Duke' and 'Liberty' highbush blueberry on 17 Oct. 2008 , after the second growing season $(\mathrm{n}=5)$.

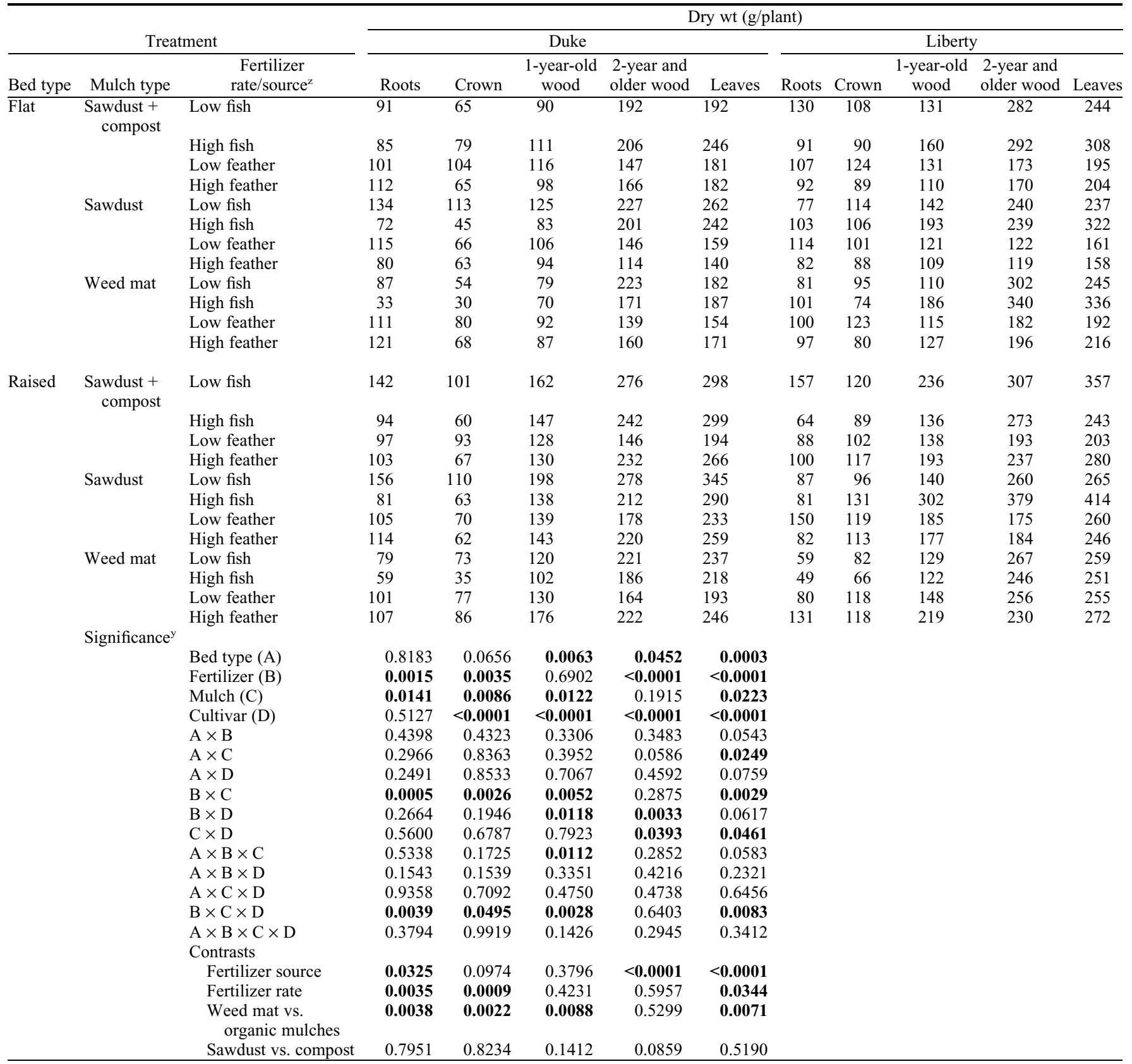

${ }^{\mathrm{z}}$ Fish emulsion and feather meal were applied at a low $\left(29 \mathrm{~kg} \cdot \mathrm{ha}^{-1}\right)$ or high $\left(57 \mathrm{~kg} \cdot \mathrm{ha}^{-1}\right)$ rate.

${ }^{\mathrm{y}}$ Bold font is used to designate values with $P<0.05$.

produced larger and heavier fruit on raised beds than on flat beds (Fig. 7A). 'Duke', however, produced lighter fruit when fertilized with a high rate of fish emulsion compared with a low rate of fish emulsion or either rate of feather meal (Fig. 7B). Mulch effects on berry weight were complex as a result of differences in yield/plant (Fig. 6C), but berry weight was reduced with weed mat compared with either organic mulch in 'Duke'; in contrast, weed mat increased berry weight in 'Liberty' compared with either organic mulch (Fig. 7C).

Biomass allocation. Annual biomass accumulation, in the second growing season, continued to be affected by fertilizer, mulch, and cultivar and/or interactions among them in each plant part, including fruit (Table 3). Plants allocated more biomass to root and crown tissue than to wood and leaves when fertilized with feather meal (Table 3). More biomass was allocated to fruit in 'Duke' when fertilized with fish emulsion (Table 3). Plants also allocated more biomass to fruit when mulched with weed mat than when mulched with either organic mulch but no longer allocated more biomass to wood and leaves with weed mat (Table 3). Annual biomass production in 2008, including fruit and leaves, averaged $2420 \mathrm{~kg} \cdot \mathrm{ha}^{-1} \mathrm{DW}$.

When calculated as a percentage of standing biomass, allocation to fruit averaged $6 \%$ in 'Duke' and $8 \%$ in 'Liberty' (data not shown). Plants grown on weed mat allocated less biomass to the roots and 1-year-old wood but more to the 2-year-old wood than those grown on sawdust or compost + sawdust. Allocation of biomass to the root system decreased with fertilizer rate $(14 \%$ at low rate to $12 \%$ at high rate) and when fish emulsion was used (11\%) compared with feather meal $(15 \%)$; the same pattern of response was observed in allocation to the crown. Root-to-shoot ratios were higher with feather meal than with fish emulsion, but there was greater difference in flat beds than in raised beds (Fig. 8A). After the second growing season, root-to-shoot ratios were no longer consistently higher with sawdust or compost + sawdust mulch than with weed mat (Fig. 8B). 

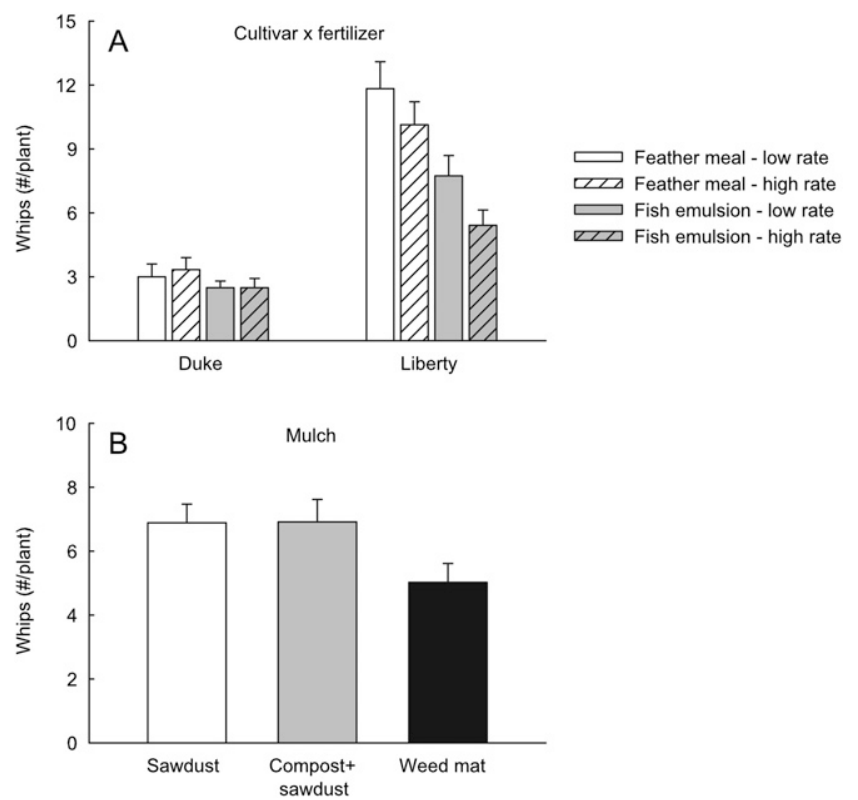

Fig. 5. Interaction effects of cultivar and fertilizer (A) and the main effect of mulch (B) on new whips per plant in 'Duke' and 'Liberty' blueberry after the second growing season. The plants were grown on flat and raised planting beds mulched with sawdust, compost topped with sawdust, or weed mat and were fertilized with feather meal or fish emulsion at low or high rates with 29 and $59 \mathrm{~kg} \cdot \mathrm{ha}^{-1}$ nitrogen $(\mathrm{N})$, respectively. Mean $\pm \mathrm{SE}$
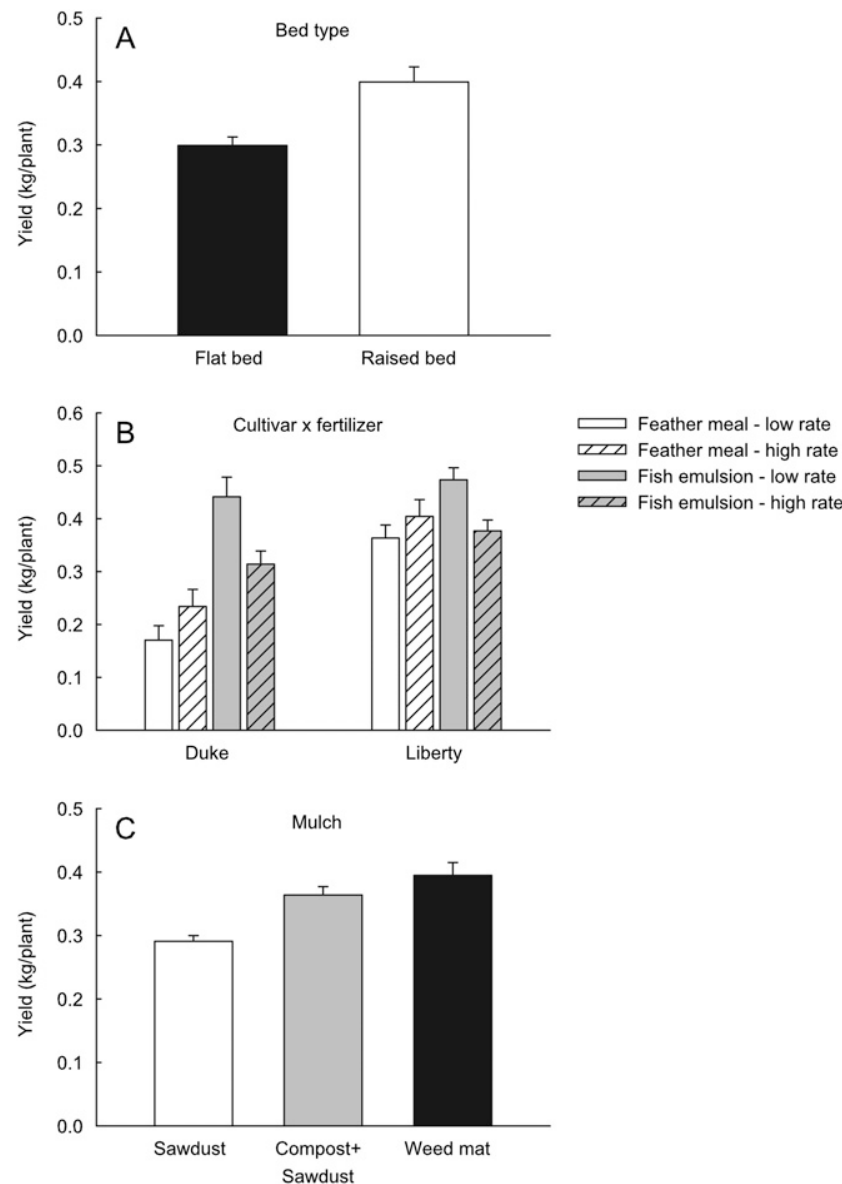

Fig. 6. Main effect of bed type (A), interaction effect of cultivar and fertilizer (B), and main effect of mulch (C) on yield in 'Duke' and 'Liberty' blueberry during the second growing season. The plants were grown on flat and raised planting beds mulched with sawdust, compost topped with sawdust, or weed mat and were fertilized with feather meal or fish emulsion at low or high rates with 29 and $59 \mathrm{~kg} \cdot \mathrm{ha}^{-1}$ nitrogen $(\mathrm{N})$, respectively. Mean $\pm \mathrm{SE}$.

\section{Discussion}

Planting on raised beds improved aboveground growth relative to flat beds but had no effect on belowground growth after two growing seasons. Although raised beds may help prevent saturated soils, reduce compaction, and improve internal drainage (Magdoff and Van Es, 2000), we did not measure improved root and crown growth (DW) after two growing seasons on raised beds compared with flat beds. Improved top growth and higher yields in the second growing season may have been associated with higher photosynthetic rates found in blueberries grown on less saturated soil (Davies and Flore, 1986). In our study, higher yields were associated with a greater aboveground growth (more growth in 2007 was correlated with higher yield in 2008) and a $10 \%$ increase in berry weight on raised beds compared with flat beds. The larger canopies and greater leaf area of plants grown on raised beds may have increased photosynthesis and availability of carbohydrates for berry growth (ValenzuelaEstrada, 2008).

Fish emulsion fertilizer also improved plant growth in the study relative to feather meal during the first season. This likely happened because the first application of feather meal, applied on 3 Apr., was not thoroughly washed into the root zone as a result of little rainfall that spring $(72 \mathrm{~mm}$ of rainfall from 3 Apr. to 16 May 2007). Growth was also less with feather meal when plants were mulched with sawdust. Sawdust immobilizes N from conventional granular fertilizers (White, 2006). In our study, sawdust mulch, which had a high $\mathrm{C}: \mathrm{N}$ ratio (Larco, 2010), likely immobilized more $\mathrm{N}$ with feather meal, a granular product applied twice, than with fish emulsion applied as a liquid in seven equal applications. Although a low rate of fish emulsion was applied to feather meal plots in June 2007 to improve plant nutrient status (Larco, 2010) and prevent plant loss, it was clear that by the end of the first growing season, the additional fertilizer did not lead to as much plant growth in feather meal plots as the fish emulsion treatments alone. Young blueberry plants have been shown to take up fertilizer $\mathrm{N}$ early in the season (Bañados et al., 2012), and it is likely that insufficient $\mathrm{N}$ was available in the feather meal treatments early on.

Although fish emulsion improved growth relative to feather meal in the establishment year, this was not the case in the second growing season. Feather meal was applied a month earlier the second year and spring rainfall was more abundant. Fertilizer source did not affect new shoot growth the second year but did affect DW of 2-year-old wood, which undoubtedly was a carryover effect from the previous year.

Plants fertilized with fish emulsion allocated less standing and annual biomass to roots and had lower root-to-shoot ratios than those fertilized with feather meal, especially when grown on weed mat. Less biomass was allocated to roots for plants grown with weed mat compared with either organic mulch after 

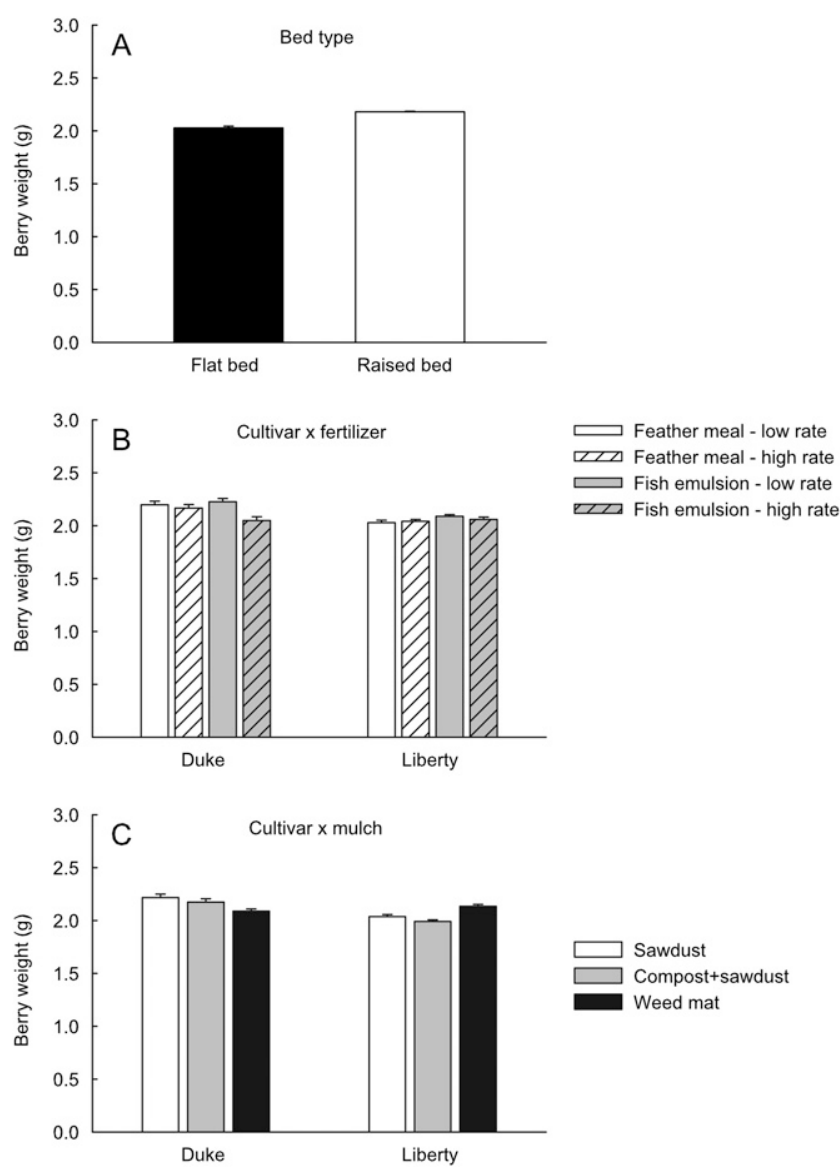

Fig. 7. Main effect of bed type (A) and interaction effects of cultivar and fertilizer (B) and cultivar and mulch $(\mathbf{C})$ on average individual berry weight in 'Duke' and 'Liberty' blueberry during the second growing season. The plants were grown on flat and raised planting beds mulched with sawdust, compost topped with sawdust, or weed mat and were fertilized with feather meal or fish emulsion at low or high rates with 29 and $59 \mathrm{~kg} \cdot \mathrm{ha}^{-1}$ nitrogen $(\mathrm{N})$, respectively. Mean $\pm \mathrm{sE}$.

the second growing season. After both growing seasons, plants grown with weed mat had a lower root-to-shoot ratio than those grown with either organic mulch.

Use of organic mulches has been shown to improve top growth in blueberry compared with no mulch or bare ground with weed control (Clark and Moore, 1991; Goulart et al., 1997; Pliszka et al., 1993; Savage, 1942; White, 2006). Krewer et al. (2009) also found an improvement of top growth with weed mat compared with organic mulches. Although organic mulches have been shown to improve root growth and distribution relative to bare soil in blueberry (Spiers, 1986; White, 2006; Wu et al., 2006), no work has been published until now on the impact of weed mat on blueberry root growth. Although the compost + sawdust mulch increased weed presence and weed control costs relative to sawdust mulch alone (Julian et al., 2012), weeds were controlled in all treatments allowing for a comparison of the effect of the mulches studied on blueberry growth and yield.

The reduction in root DW under weed mat, particularly in 'Duke', may have been a result of elevated soil temperatures $\left(\approx 5^{\circ} \mathrm{C}\right.$ higher at $5-\mathrm{cm}$ depth under weed mat vs. organic mulches on raised beds; Larco, 2010) or as a result of a decline in soil porosity or water infiltration rates as found by others in blueberry (Cox, 2009) and apple (Malus domestica Borkh.; Neilsen et al., 2003). Weed mat may also have altered nutrient availability compared with the organic mulches, affecting root or top growth. Although our goal was to maintain soil water content at a similar level among planting method and mulch treatments in our study, it is possible that slight differences in soil water content or irrigation frequency among treatments may have affected root or canopy growth (Bryla et al., 2011; Larco, 2010). Decreased soil water infiltration rate and increased bulk density were shown in apple grown with weed mat compared with organic mulches, but these effects were not correlated with yield (Neilsen et al., 2003).

The root-to-shoot ratio increased from an average of 0.43 in Fall 2007 to 0.50 in 2008 . Others have reported a root-to-shoot ratio of 1.67 to 1.43 in 4-year-old 'Duke' (Bryla and Strik, 2007; Strik and Buller, 2005). It is possible that root-to-shoot ratio increases from the time of planting to maturity. The root-to-shoot ratio measured in our study was slightly lower than the 0.48 to 0.83 reported for 'Bluecrop' after one growing season in conventional production (Bañados et al., 2012). Root-to-shoot ratio is likely affected by cultivar, particularly in young plants, as reported here. In our study, higher rates of fertilizer reduced biomass allocation to roots, decreasing root-to-shoot ratio, agreeing with what has been reported for young plants fertilized with various rates of $\mathrm{N}$ in a conventional production system (Bañados et al., 2012).

The highest yields in our study were found when plants were fertilized with the lowest rate of fish emulsion in 'Duke' and with a similar trend for 'Liberty'. In other studies, the response of young blueberry plants to rate of inorganic $\mathrm{N}$ fertilizer has been variable. For example, Bañados et al. (2012) found that a lower rate of $50 \mathrm{~kg} \cdot \mathrm{ha}^{-1} \mathrm{~N}$ with conventional fertilizer produced more plant DW and yield than two higher $\mathrm{N}$ rates in 'Bluecrop' blueberry during the first 2 years after planting, whereas White (2006) found no effect of $\mathrm{N}$ fertilizer rate on yield of 'Elliott' in the third growing season. Based on our results and those reported by others using conventional fertilizers (Bañados et al., 2012; Cummings, 1978; White, 2006), it is clear that overapplication of $\mathrm{N}$ fertilizer in young, fieldgrown highbush blueberry plants can reduce growth and yield.

In both cultivars, plants mulched with sawdust produced a lower yield on average than those mulched with compost + sawdust or weed mat. Interestingly, addition of compost to sawdust mulch increased shoot growth and total plant DW at the end of the first growing season, but it had no impact by the end of the second growing season. The longterm effects of compost mulch on plant and soil nutrient status need to be assessed.

Plants grown on raised beds and fertilized with the low rate of fish emulsion produced the highest yields in both cultivars when mulched with weed mat or compost + sawdust ( 0.56 to $0.57 \mathrm{~kg} / \mathrm{plant})$. Yield of organic rabbiteye blueberry plants (generally higher yielding than northern highbush types) grown with pine straw, weed mat, and pine bark was $0.9,0.7$, and $0.6 \mathrm{~kg} /$ plant, respectively, after the second growing season (Krewer et al., 2009). In conventional northern highbush production systems in Oregon, 'Elliott', 'Bluecrop', and 'Duke' planted at 1.2-m spacing in the row produced $0.95,0.82$, and $0.66 \mathrm{~kg} / \mathrm{plant}$, respectively, in the second growing season (Strik and Buller, 2005). The plant yield in our study may have been lower than reported for conventional production systems in Oregon because 1) rainfall during bloom reduced percent fruit set (Strik, personal observation); 2 ) yield per plant was reduced at the higher planting density (0.76-m spacing) in our study as has been reported with other high-density plantings (Strik and Buller, 2005); and/or 3 ) because plants are slower to establish in organic systems. It will be important to assess the long-term impact of organic production systems on yield.

Although allocation of standing biomass to the leaves, crown, and shoots was similar to that reported by Bañados et al. (2012) for conventional 'Bluecrop' plants of the same age, plants in our study allocated less biomass to the roots, on average, likely because weed 
Table 3. The effect of fertilizer source and rate and mulch type on the allocation of dry weight of 'Duke' and 'Liberty' highbush blueberry on 17 Oct. 2008 , after the second growing season, averaged over bed type.

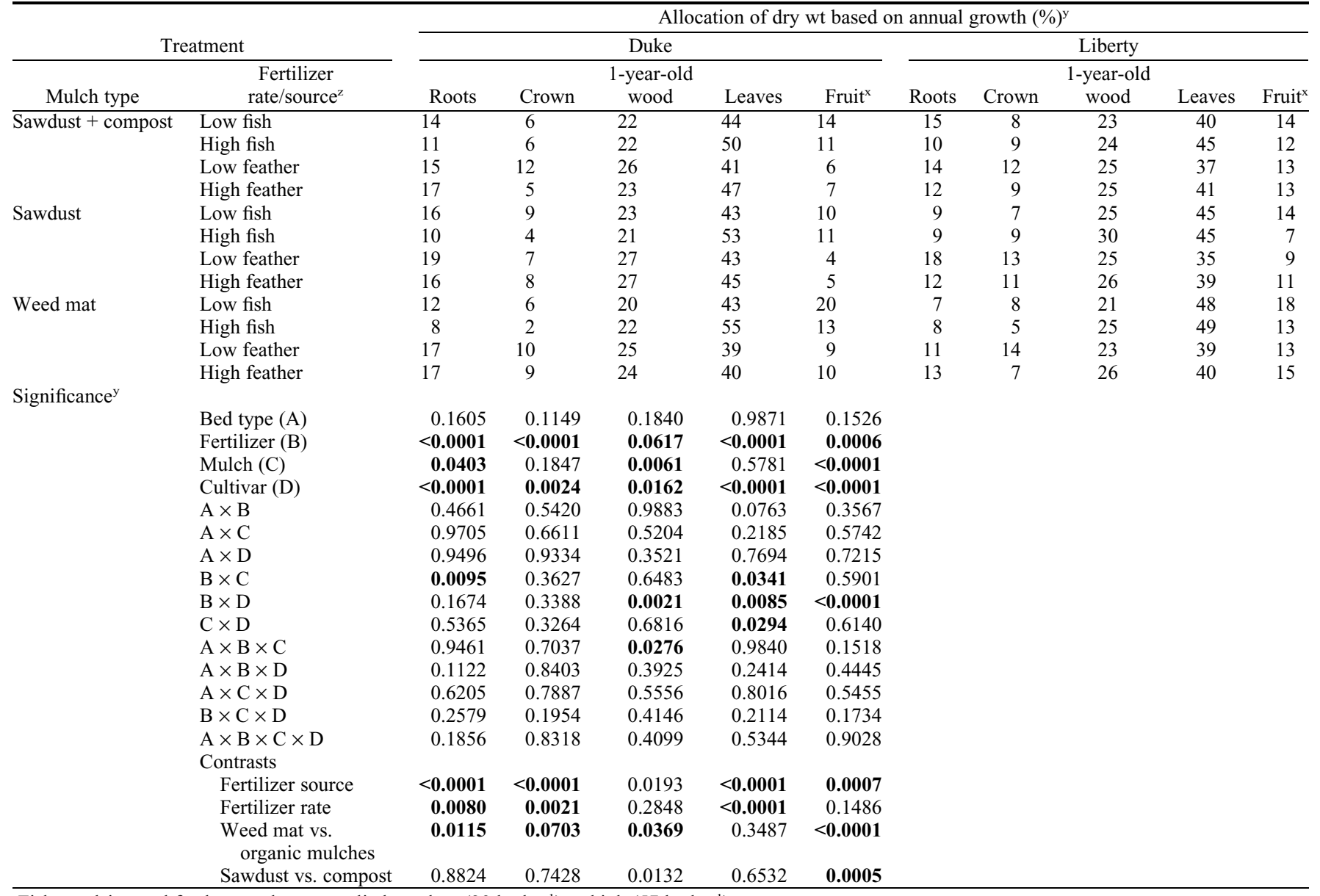

${ }^{\mathrm{z}}$ Fish emulsion and feather meal were applied at a low $\left(29 \mathrm{~kg} \cdot \mathrm{ha}^{-1}\right)$ or high $\left(57 \mathrm{~kg} \cdot \mathrm{ha}^{-1}\right)$ rate.

${ }^{\text {y } B o l d ~ f o n t ~ i s ~ u s e d ~ t o ~ d e s i g n a t e ~ v a l u e s ~ w i t h ~} P<0.05$.

mat and the high rate of fish emulsion fertilizer increased biomass allocation to aboveground growth. The reproductive effort of these young plants, $4 \%$ to $20 \%$ of annual growth and $6 \%$ to $8 \%$ of standing biomass, was much less than the values $(55 \%$ and $22 \%$, respectively) reported for older (3+ years) wild highbush blueberry plants (Pritts and Hancock, 1985). Reproductive effort may increase with plant age in blueberry but is also likely affected by pruning and fertilizer, neither of which was used in the wild plants.

The DW of 1-year-old shoots measured after the first growing season was positively correlated with fruit DW in the second growing season. Thus, treatments that improve early shoot growth may increase early production. After two growing seasons, shoot growth was greatest on raised beds in both cultivars; however, 'Duke' and 'Liberty' responded differently depending on the production system. For example, 'Duke' plants mulched with sawdust or compost + sawdust had the most shoot growth when fertilized with a low rate of fish emulsion, whereas 'Duke' plants mulched with weed mat had more shoot growth when fertilized with a high rate of feather meal. In 'Liberty', shoot growth was best when plants were mulched with sawdust and fertilized with a high rate of fish emulsion, but when plants were mulched with compost + sawdust, shoot growth was improved by fertilizing with a low rate of fish emulsion. However, there was relatively little impact of fertilizer source or rate when 'Liberty' plants were mulched with weed mat. Fertilizer $\mathrm{N}$ was more available under weed mat mulch than under sawdust (Larco, 2010), likely affecting the blueberry plant responses to the fertilizer treatments.

In general, 'Liberty' grew faster and was more vigorous than 'Duke' in both growing seasons. 'Liberty' produced more whips/ plant than 'Duke', which is typical in commercial production systems (Strik, personal observation). White (2006) observed that more whips were produced in young 'Elliott' plants with sawdust mulch than without it. Although there was sawdust mulch in the area around the plant crown in the weed mat treatment, whip production was still reduced, especially when plants were grown on raised beds. Soil temperature was higher under weed mat than under sawdust (Larco, 2010), but the impact of soil temperature on whip production has not been studied to date. The effect of these treatments on long-term cane renewal is not known at this time.

\section{Conclusions}

In the organic production systems studied, the greatest plant growth and yield, after two growing seasons, were generally found when plants were grown on raised beds, were fertilized with the low rate of fish emulsion, and were mulched with either compost + sawdust or weed mat.

The impact of these organic production treatments on root growth may affect sustainability, because plants with large canopies and small root systems may be less tolerant of cultural or environmentally induced stress. The lower root-to-shoot ratios in plants grown with weed mat or compost + sawdust or in those fertilized with fish emulsion and higher rates of fertilizer may improve plant yield in the short term but may have longer-term consequences.

In the northwestern United States, establishing new plantings on raised beds with weed mat mulch is becoming common in organic production (Julian et al., 2011b) because weed mat improves weed control and increases economic returns (Julian et al., 2012). In our study, 'Duke' and 'Liberty' grown on raised beds with weed mat had the greatest root and top growth when fertilized with the high rate of feather meal. We 

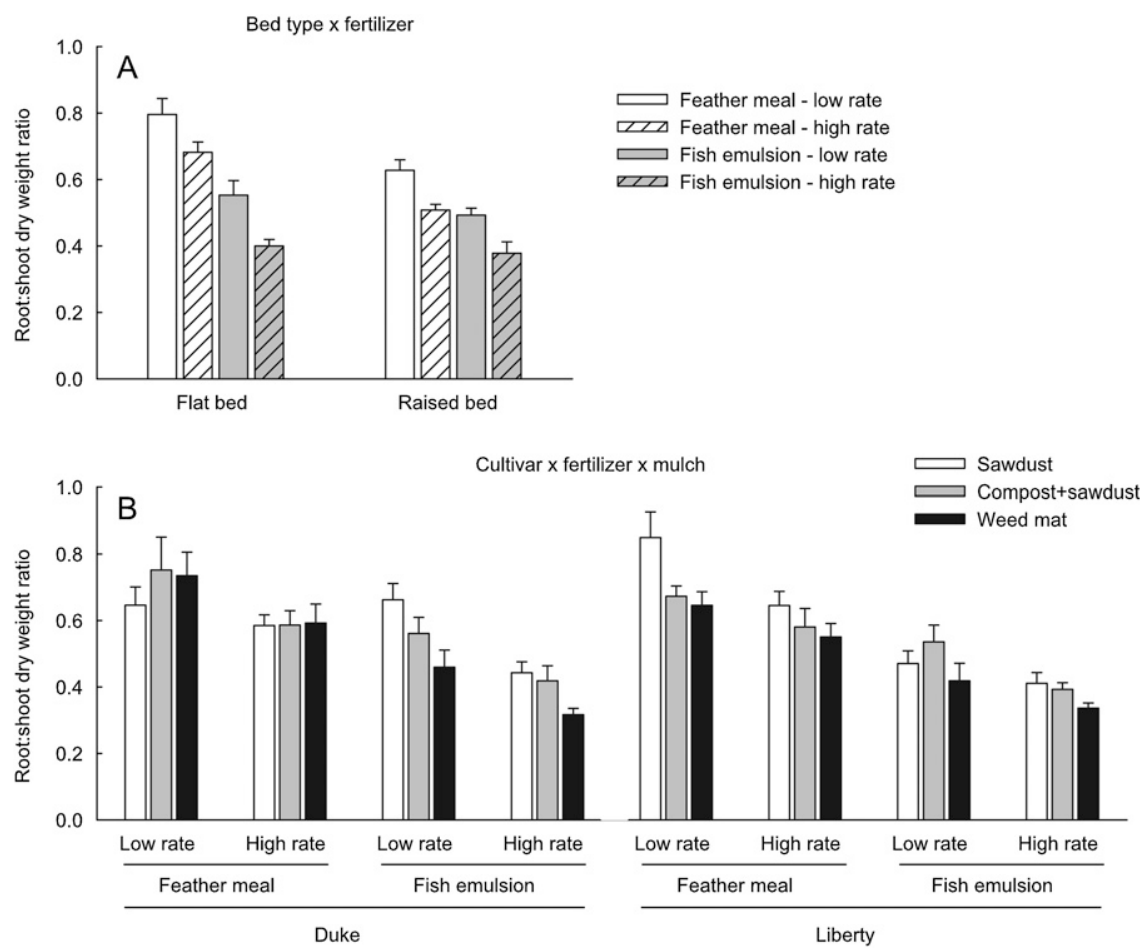

Fig. 8. Interaction effects of bed and fertilizer $(\mathbf{A})$ and cultivar, fertilizer, and mulch $(\mathbf{B})$ on dry weight ratio of roots (including the crown) to shoots (woody stems) in 'Duke' and 'Liberty' blueberry after the second growing season. The plants were grown on flat and raised planting beds mulched with sawdust, compost topped with sawdust, or weed mat and were fertilized with feather meal or fish emulsion at low or high rates with 29 and $59 \mathrm{~kg} \cdot \mathrm{ha}^{-1}$ nitrogen $(\mathrm{N})$, respectively. Mean $\pm \mathrm{SE}$.

will next evaluate the impacts of these treatments on soil and plant nutrient status and irrigation requirements during planting establishment.

\section{Literature Cited}

Bañados, M.P. 2006. Dry weight and ${ }^{15} \mathrm{~N}$-nitrogen and partitioning, growth, and development of young and mature blueberry plants. PhD thesis, Oregon State University. <http://ir.library. oregonstate.edu/xmlui/bitstream/handle/1957/ 9649/Banados_Maria_P 2006.pdf? sequence $=1>$.

Bañados, M.P., B.C. Strik, D.R. Bryla, and T.L. Righetti. 2012. Response of highbush blueberry to nitrogen fertilizer during field establishment. I. Accumulation and allocation of fertilizer nitrogen and biomass. HortScience 47:648-655.

Bryla, D.R., J.L. Gartung, and B.C. Strik. 2011 Evaluation of irrigation methods for highbush blueberry-I. Growth and water requirements of young plants. HortScience 46:95-101.

Bryla, D.R. and R.G. Linderman. 2007. Implications of irrigation method and amount of water application on Phytophthora and Pythium infection and severity of root rot in highbush blueberry. HortScience 42:1463-1467.

Bryla, D.R. and B.C. Strik. 2007. Effects of cultivar and plant spacing on the seasonal water requirements of highbush blueberry. J. Amer. Soc. Hort. Sci. 132:270-277.

Burkhard, N., D. Lynch, D. Percival, and M. Sharifi. 2009. Organic mulch impact on vegetation dynamics and productivity of highbush blueberry under organic production. HortScience 44:688-696.

Chandler, R.B. and E.C. Mason. 1942. The effect of mulches on soil moisture, soil temperature, and growth of blueberry plants. Proc. Amer. Soc. Hort. Sci. 40:335-337.
Clark, J.R. and J.N. Moore. 1991. Southern highbush blueberry response to mulch. HortTechnology 1:52-54.

Costello, R.C. 2011. Suitability of diverse composts as soil amendments for highbush blueberry (Vaccinium corymbosum L.). MS thesis, Ore. St. Univ., Corvallis, OR. <http://hdl.handle. net/1957/26590>.

Cox, J. 2009. Comparison of plastic weedmat and woodchip mulch on low chill blueberry soil in New South Wales, Australia. Acta Hort 810:475-482.

Cummings, G.A. 1978. Plant and soil effects of fertilizer and lime applied to highbush blueberries. J. Amer. Soc. Hort. Sci. 103:302-305.

Davies, F.S. and J.F. Flore. 1986. Gas exchange and flooding stress of highbush and rabbiteye blueberries. J. Amer. Soc. Hort. Sci. 111:565-571.

Eck, P. 1988. Blueberry science. Rutgers Univ. Press, New Brunswick, NJ. p. 135-169.

Fausey, J.C. 2003. Controlling liverwort and moss now and in the future. HortTechnology 13:3538.

Gale, E.S., D.M. Sullivan, D. Hemphill, C.G. Cogger, A.I. Bary, and E.A. Myhre. 2006. Estimating plant-available nitrogen release from manures, composts, and specialty products. J. Environ. Qual. 35:2321-2332.

Goulart, B.L., K. Demchak, and W.Q. Yang. 1997. Effect of cultural practices on field grown 'Bluecrop' highbush blueberries, with emphasis on mycorrhizal infection levels. Acta Hort. 446:271-278

Granatstein, D. and K. Mullinix. 2008. Mulching options for northwest organic and conventional orchards. HortScience 43:45-50.

Griggs, W.H. and H.A. Rollins. 1947. The effect of planting treatment and soil management systems on the production of cultivated blueberries. Proc. Amer. Soc. Hort. Sci. 49:213-218.
Hanson, E.J. 2006. Nitrogen nutrition of highbush blueberry. Acta Hort. 715:347-351.

Hart, J., B. Strik, L. White, and W. Yang. 2006. Nutrient management for blueberries in Oregon. Oregon State Univ. Ext. Ser. Pub., EM 8918.

Julian, J., B. Strik, and W. Yang. 2011a. Blueberry economics: The costs of establishing and producing blueberries in the Willamette Valley, Oregon. AEB 0022. <http://arec.oregonstate. edu/oaeb/files/pdf/AEB0022.pdf>.

Julian, J., B. Strik, E. Pond, and W. Yang. 2011b. Blueberry economics: The costs of establishing and producing organic blueberries in the Willamette Valley, Oregon. Oregon State Univ. Pub. AEB 0023. <http://arec.oregonstate.edu/ oaeb/files/pdf/AEB0023.pdf $>$.

Julian, J.W., B.C. Strik, H.O. Larco, D.R. Bryla, and D.M. Sullivan. 2012. Cost of establishing organic northern highbush blueberry: Impacts of planting method, fertilization, and mulch type. HortScience 47:866-873.

Karp, K., M. Noormets, M. Starast, and T. Paal. 2006. The influence of mulching on nutrition and yield of 'Northblue' blueberry. Acta Hort. 715:301-305.

Kozinski, B. 2006. Influence of mulching and nitrogen fertilization rate on growth and yield of highbush blueberry. Acta Hort. 715:231235.

Krewer, G., M. Tertuliano, P. Andersen, O. Liburd, G. Fonsah, H. Serri, and B. Mullinix. 2009. Effect of mulches on the establishment of organically grown blueberries in Georgia. Acta Hort. 810:483-488.

Larco, H.O. 2010. Effect of planting method, weed management, and fertilizer on plant growth and yield of newly established organic highbush blueberries. MS thesis, Oregon State Univ., Corvallis, OR. <http://ir.library.oregonstate.edu/ xmlui/handle/1957/18065>.

Magdoff, F. and H. Van Es. 2000. Building soils for better crops. Sustainable Agriculture Network for the Sustainable Agriculture Research and Education Program of the Cooperative State Research, Education, and Extension Service. 2nd Ed. p. 75, 133

Magee, J.B. and J.M. Spiers. 1995. Influence of mulching systems on yield and quality of southern highbush blueberries. In: Gough, R.E. and R.F. Korcak (eds.). Blueberries: A century of research. Haworth Press, Inc., Binghamton, NY.

Neilsen, G.H., E.J. Hogue, T. Forge, and D. Neilsen. 2003. Mulches and biosolids affect vigor, yield, and leaf nutrition of fertigated high density apple. HortScience 38:41-45.

Pliszka, K., K. Ścibisz, and H. Rojek. 1993. The effect of soil, management and mineral fertilization upon growth and cropping of the highbush blueberry cv. 'Bluecrop' Acta Hort. 346:149-154.

Pritts, M.P. and J.F. Hancock. 1985. Lifetime biomass partitioning and yield component relationships in the highbush blueberry, Vaccinium corymbosum L. (Ericaceae). Amer. J. Bot. 72: 446-452.

Pritts, M.P. and J.F. Hancock. 1992. Highbush blueberry production guide. NRAES-55, Ithaca, NY.

Runham, S.R., S.J. Town, and J.C. Fitzpatrick. 2000. Evaluation over four seasons of a paper mulch used for weed control in vegetables. Acta Hort. 513:193-201.

Savage, E.F. 1942. Growth responses of blueberries under clean cultivation and various kinds of mulch materials. Proc. Amer. Soc. Hort. Sci. 40:335-337. 
Sciarappa, W., S. Polavarapu, J. Barry, P. Oudemans, M. Ehlenfeldt, G. Pavlis, D. Polk, and R. Holdcraft. 2008. Developing an organic production system for highbush blueberry. HortScience 43:51-57.

Sikora, L.J. and R.A.K. Szmidt. 2001. Nitrogen sources, mineralization rates, and nitrogen nutrition benefits to plants from composts, p. 287-305. In: Stofella, P.J. and B.A. Kahn (eds.). Compost utilization in horticultural cropping systems. CRC Press, Boca Raton, FL.

Spiers, J.M. 1986. Root distribution of 'Tifblue' rabbiteye blueberry as influenced by irrigation, incorporated peatmoss, and mulch. J. Amer. Soc. Hort. Sci. 111:877-880.

Spiers, J.M. 1995. Substrate temperatures influence root and shoot growth of southern highbush and rabbiteye blueberries. HortScience 30:10291030.

Spiers, J.M. 2000. Influence of cultural practices on root distribution of 'Gulfcoast' blueberry. Acta Hort. 513:247-252.

Strik, B. 2007. Horticultural practices of growing highbush blueberries in the ever-expanding U.S. and global scene. J. Amer. Pomol. Soc. 61:148-150.

Strik, B., C. Brun, M. Ahmedullah, A. Antonelli, L. Askam, D. Barney, P. Bristow, G. Fisher, J. Hart, D. Havens, R. Ingham, D. Haufman, R. Penhallegon, J. Psheidt, B. Scheer, C. Shanks, and R. Williams. 1993. Highbush blueberry production. Pacific Northwest Extension Bulletin 215. Oregon State University, Corvallis, OR.

Strik, B. and G. Buller. 2005. The impact of early cropping on subsequent growth and yield of highbush blueberry in the establishment years at two planting densities is cultivar dependent. HortScience 40:1998-2001.

Strik, B. and D. Yarborough. 2005. Blueberry production trends in North America, 1992 to 2003 and predictions for growth. HortTechnology 15:391-398.

Sullivan, D.M., N. Andrews, J.M. Luna, and J.P.G. McQueen. 2010. Estimating N contribution from organic fertilizers and cover crop residues using online calculators, p. 83-86. In: Proc. 2010 19th World Congress of Soil Science, Soil Solutions for a Changing World, 1-6 Aug. 2010, Brisbane, Australia. <http://www.iuss.org/ 19th\%20WCSS/Symposium/pdf/D3.2.pdf $>$.

Throop, P.A. and E.J. Hanson. 1997. Effect of application date on absorption of ${ }^{15} \mathrm{~N}$ by highbush blueberry. J. Amer. Soc. Hort. Sci. 122:422-426.

USDA. 2010. Organic production survey (2008). Vol. 3. Special studies, part 2. 2007 Census of Agr. Updated July 2010.

USDA-AMS-NOP. 2011. Program handbook: Guidance and instructions for accredited certifying agents \& certified operations. Winter edition.

Valenzuela-Estrada, L.R. 2008. Above- and belowground physiology in Vaccinium corymbosum L. (northern highbush blueberry) in response to water stress and reproductive effort. $\mathrm{PhD}$ thesis, Pennsylvania State Univ., University Park, PA.

Valenzuela-Estrada, L.R., J. Richards, A. Diaz, and D. Eissensat. 2009. Patterns of nocturnal dehydration in root tissues of Vaccinium corymbosum L. under severe drought conditions. J. Expt. Bot. 60:1241-1247.

Webber, C.L., M.A. Harris, J.W. Sherefler, M. Durnova, and C.A. Christopher. 2005. Vinegar as an organic burn-down herbicide, p. 168-172. Proc. of the 24th annual Oklahoma and Arkansas horticulture industries show. Fort Smith, AK

White, L.D. 2006. The effect of pr-plant incorporation with sawdust, sawdust mulch, and nitrogen fertilizer rate on soil properties and nitrogen uptake and growth of 'Elliott' highbush blueberry. MS thesis, Oregon State Univ., Corvallis, OR. <http://ir.library.oregonstate.edu/ xmlui/bitstream/handle/1957/1363/WholeThesis. pdf? sequence $=1>$.

Williamson, J., G. Krewer, G. Pavlis, and C.M Mainland. 2006. Blueberry soil management, nutrition and irrigation. In: Childers, N.F. and P.M. Lyrene (eds.). Blueberries for growers, gardeners and promoters. E.O., Gainesville, FL.

Wu, L., H. Yu, L. Dong, Y. Zhu, C. Li, Z. Zhang, and Y. Li. 2006. Comparison of mulching treatments on growth and physiology of highbush blueberry. Acta Hort. 715:237-240.

Young, S.L. 2004. Natural product herbicides for control of annual vegetation along roadsides. Weed Technol. 18:580-587. 